\title{
Isolation of plant nuclei suitable for flow cytometry from species with extremely mucilaginous compounds: an example in the genus Viola L. (Violaceae)
}

\author{
by \\ Eduardo Cires ${ }^{1 *}$, Candela Cuesta ${ }^{2,3^{*}}$, María Ángeles Fernández Casado ${ }^{1}$, Herminio S. Nava $^{1}$, \\ Víctor M. Vázquez ${ }^{4} \&$ José Antonio Fernández Prieto ${ }^{1}$ \\ ${ }^{1}$ Área de Botánica, Universidad de Oviedo, Departamento de Biología de Organismos y Sistemas, Catedrático Rodrigo Uría s/n, \\ E-33071 Oviedo, Spain. Corresponding author: Phone: +34 985 104835; fax: +34 985 104777; e-mail: cireseduardo@gmail.com \\ ${ }^{2}$ Department of Plant Systems Biology, VIB, Technologiepark 927, 9052 Gent, Belgium. candelacuesta@gmail.com \\ ${ }^{3}$ Área de Fisiología Vegetal, Universidad de Oviedo, Departamento de Biología de Organismos y Sistemas, \\ Catedrático Rodrigo Uría s/n, E-33071 Oviedo, Spain \\ ${ }^{4}$ Real Instituto de Estudios Asturianos, Plaza de Porlier 9, E-33003 Oviedo, Spain \\ "Both authors contributed equally to this work
}

\begin{abstract}
Cires, E., Cuesta, C., Fernández, M.A., Nava, H.S., Vázquez, V.M. \& Fernández, J.A. 2011. Isolation of plant nuclei suitable for flow cytometry from species with extremely mucilaginous compounds: an example in the genus Viola L. (Violaceae). Anales Jard. Bot. Madrid 68(2): 139-154.

Flow cytometry analysis has been widely applied in the determination of nuclear DNA content and ploidy level in many organisms. Despite being the most appropriate method for DNA content measurement, flow cytometry also presents some limitations. A fairly common, but little-studied problem is the effect on measurements of the presence of secondary metabolites. A good example is the genus Viola, which is composed of 525-600 species distributed worldwide. These species have proved to be problematic for flow cytometric analyses due to the release of extremely mucilaginous compounds into the nuclear suspension. In this work, the genome size of 13 species of Viola using flow cytometry are presented for the first time. Despite obtaining histograms with high coefficients of variation, we here present an optimized protocol to remove cytoplasmic compounds, particularly mucilaginous ones, from plant nuclei that pave the way for its application to estimate the genome size of other species exhibiting similar problems. Statistical analyses revealed significant differences between sections Viola and Melanium, and within each section $(P<0.001)$. Furthermore, statistically significant differences were not detected among samples of the same species.
\end{abstract}

\section{Resumen}

Cires, E., Cuesta, C., Fernández, M.A., Nava, H.S., Vázquez, V.M. \& Fernández, J.A. 2011. Aislamiento de núcleos para citometría de flujo en plantas con alto contenido de compuestos mucilaginosos: un ejemplo en el género Viola L. (Violaceae). Anales Jard. Bot. Madrid 68(2): 139-154 (en inglés).

El análisis mediante citometría de flujo ha sido aplicado de modo general para determinar el contenido de ADN nuclear y el nivel de ploidía en muchos organismos. A pesar de ser el método más adecuado para medir la cantidad de ADN, esta técnica también presenta algunas limitaciones. Un problema bastante común, aunque poco estudiado, es el efecto de los metabolitos secundarios en los resultados obtenidos. Un ejemplo respecto a la presencia de estos compuestos se encuentra en el género Viola, compuesto por 525-600 especies distribuidas por todo el mundo. Las especies de este género ya han sido previamente descritas como problemáticas en los análisis de citometría de flujo debido a la presencia de compuestos extremadamente mucilaginosos en las suspensiones de núcleos. En el presente trabajo se analiza por primera vez el tamaño genómico de 13 especies del genero Viola mediante el empleo de citometría de flujo. A pesar de los altos valores mostrados en los coeficientes de variación de los histogramas, se presenta un protocolo optimizado para eliminar compuestos citoplasmáticos, y más concretamente mucilaginosos de las suspensiones nucleares, siendo de aplicación en la estimación del tamaño genómico de plantas con problemas similares. Los análisis estadísticos mostraron diferencias significativas entre las secciones Viola y Melanium, así como dentro de cada sección $(P<0,001)$. Además, no se encontraron diferencias significativas entre aquellas muestras pertenecientes a la misma especie. 
Keywords: Chromosome number, flow cytometry, genome size, mucilaginous compounds, nuclear DNA content, ploidy levels, section Melanium, section Viola. Abbreviations: CV: coefficient of variation; DI: DNA index; FCM: flow cytometry; PI: propidium iodide.

\section{Introduction}

Flow cytometry $(\mathrm{FCM})$ is a fast, sensitive technique for measuring specific components in large numbers of cells and organelles. Plant scientists have been attracted by the numerous advantages of this technique (e.g. ease of sample preparation, speed of analysis, and no requirement for dividing cells) and the number of articles related to this technique has been continuously increasing over the years (Doležel \& al., 2007a). Estimation of DNA content in cell nuclei is one of the most important applications of FCM in plant sciences. In most plants, analyses of relative DNA content of nuclei isolated from young tissues yield histograms with good resolution. In principle, every tissue containing vital nuclei should be suitable for measurement of nuclear DNA content with FCM. However, the presence or absence of endogenous fluorescence inhibitor substances and coatings of debris influences the quality of the results (Greilhuber \& al., 2007). Plant cells produce a vast array of secondary metabolites which may interfere with staining of particular cell constituents and/or exhibit autofluorescence, thus hampering quantification of signals from fluorescent probes (Doležel \& al., 2007b). Although the interference of secondary metabolites with staining procedures had been recognized for some time in cytophotometry (e.g. Greilhuber, 1986), it was not until Noirot \& al. $(2000,2002,2003,2005)$ and Price \& al. (2000) published their findings that this effect was taken seriously in plant FCM. Moreover, some species contained mucilaginous compounds which interfered with analysis, affecting overall histogram quality and nuclear fluorescence stability (e.g. Betulaceae, Violaceae, Lythraceae, Malvaceae, Orchidaceae and submerged plants) (Suda, 2004; Loureiro, 2007; Greilhuber, 2008). Besides hampering the release of nuclei, these compounds confer a high viscosity to the nuclear suspension, which makes the filtration step difficult to accomplish and consequently results in the recovery of a low volume of nuclear homogenate. Some authors have found great difficulty in using FCM due to these compounds (e.g. Morgan \& Westoby, 2005; Talent \& Dickinson, 2005; Loureiro \& al., 2007a). To give an example, Morgan and Westoby (2005) found for many species of Myrtaceae and Rutaceae that the ineffective nuclear isolation was due to mucilaginous
Palabras clave: Número cromosomático, citometría de flujo, tamaño genómico, compuestos mucilaginosos, contenido de ADN nuclear, niveles de ploidía, sección Melanium, sección Viola.

compounds. On the other hand, Loureiro \& al. (2007b), in the study of the genera Ulmus L. and Celtis L., presented a protocol which ensured high quality analyses with a low coefficient of variation and minimal background debris as well as nuclear fluorescence stability. However, even Loureiro \& al. (2007b) found similar problems in leaves of Ulmus species, where they got poor results and had to use an alternative tissue (samaras) characterized by lower concentration of mucilaginous compounds.

The genus Viola L. includes examples of several species with extremely mucilaginous compounds. This genus, the largest of the Violaceae family, comprises 525-600 species distributed throughout most frostfree regions of the world (Ballard \& al., 1999; Yockteng \& al., 2003; Karlsson \& al., 2008). It is divided into $c a .14$ sections and many infrasectional groups (Becker 1910a, 1910b, 1925) (for a review of infrageneric classification see Ballard \& al., 1999). Five of those sections are present in Europe: Chamaemelanium Ging., Melanium Ging., Xylinosium W. Becker, Delphiniopsis W. Becker and Viola (Valentine \& al., 1968); all of which have also been described in the Iberian Peninsula (Fernández Casado, 1982; Muñoz Garmendia \& al., 1993).

In the present work, the samples selected belong to 2 of these sections: Melanium, which includes the socalled pansies and is a morphologically well-defined group of about 80-100 species; and Viola, which is a Eurasian group of about 25 species with several subsections described (Valentine \& al., 1968; Karlsson $\&$ al., 2008), of which the following were studied: Viola, Rostratae Kupffer and Stolonosae Kupffer [=Plagiostigma Godr.]. Taxa of these sections are well known for their taxonomic complexity, apparently caused by several factors: (a) scarcity of reliable diagnostic morphological characters; (b) high phenotypic plasticity; (c) frequent interspecific hybridizations; and (d) assumed past reticulate evolution within the section and subsection (Ballard \& al., 1999; Yockteng \& al., 2003; Hodálová \& al., 2008; Mered'a \& al., 2008; Van den Hof \& al., 2008).

A high diversity of chromosome numbers has been proposed within genus Viola (Moore, 1982; Castroviejo \& Valdés-Bermejo, 1991) by showing different ploidy levels (Miyaji, 1930; Karlsson \& al., 2008). The basic chromosome number approved for genus Viola 
is $x=6$, although recently $x=7$ has been suggested as an equally likely chromosome base-number, mainly based on counts of those plants considered as primitive (Sanso \& Seo, 2005; Karlsson \& al., 2008). Of the groups considered in the present study, the section Melanium is aneuploid, and the base chromosome number has been ambiguously established, with proposals of $x=11$ (Erben, 1996) or $x=5,6$ and 10, by Ballard \& al. (1999). Section Viola is allotetraploid (Nordal \& Jonsell, 1998; Marcussen \& Nordal, 1998) with secondary base-numbers of $x=10-13$ depending on the subsection (Karlsson \& al., 2008): $x=10$ in subsections Viola and Rostratae, and $x=12$ and 22 in subsection Stolonosae.

Although there are several studies that have approached genome size analysis of various species of genus Viola using FCM (Ajalin \& al., 2002; Marcussen, 2003; Hodálová \& al., 2008; Mered'a \& al., 2008), only two nuclear DNA content values have been found in the literature: $V$. anagae $2.61 \mathrm{pg} / 2 \mathrm{C}$ with unknown ploidy level (Suda \& al., 2005) and V. riviniana $2.70 \mathrm{pg} / 2 \mathrm{C}$ also with unknown ploidy level (Grime \& al., 1985), although tetraploidy is assumed by the "Angiosperm DNA C-values database" (Bennett \& Leitch, 2005) for the last species. Cytometric data gaps in this genus may be primarily due to the extreme difficulty in obtaining readable histograms due to the presence of mucilaginous compounds in nuclear suspensions that prevent the accurate reading of the data.
In this study, the nuclear DNA content of 13 species of the genus Viola were estimated for the first time using FCM. Due to the recognized problems in isolating nuclei from such species, the objective was to develop a reliable protocol to isolate nuclei in good condition from different tissues (leaves, leaf petioles and flowers) containing mucilaginous compounds.

\section{Materials and methods}

Plant material from the northwest of the Iberian Peninsula, the Pyrenees and the Alps (Figs. 1,2) were used for nuclear DNA content estimations in the genus Viola (Table 1). Plants collected in the field were cultivated in the experimental garden of the Botany Area, Oviedo University. Additionally, voucher specimens were collected and kept in the Herbarium of the University of Oviedo (FCO: 31933 31962). Ploidy levels were determined by FCM and by chromosome counting, if it was required. Chromosome counts were performed on root tips pretreated with melting ice water at $4{ }^{\circ} \mathrm{C}$ for 24 hours. Then, they were fixed in ethanol: acetic acid $(3: 1)$ for two days and finally preserved in ethanol $(70 \%)$ at low temperature. The staining was done with aceto-orcein 1\% and the slides were prepared using the squash technique (Tjio \& Levan, 1950).

Genome size was estimated using FCM. The plant standards were derived from newly expanded leaves of young greenhouse-grown plantlets of tomato (Sola-

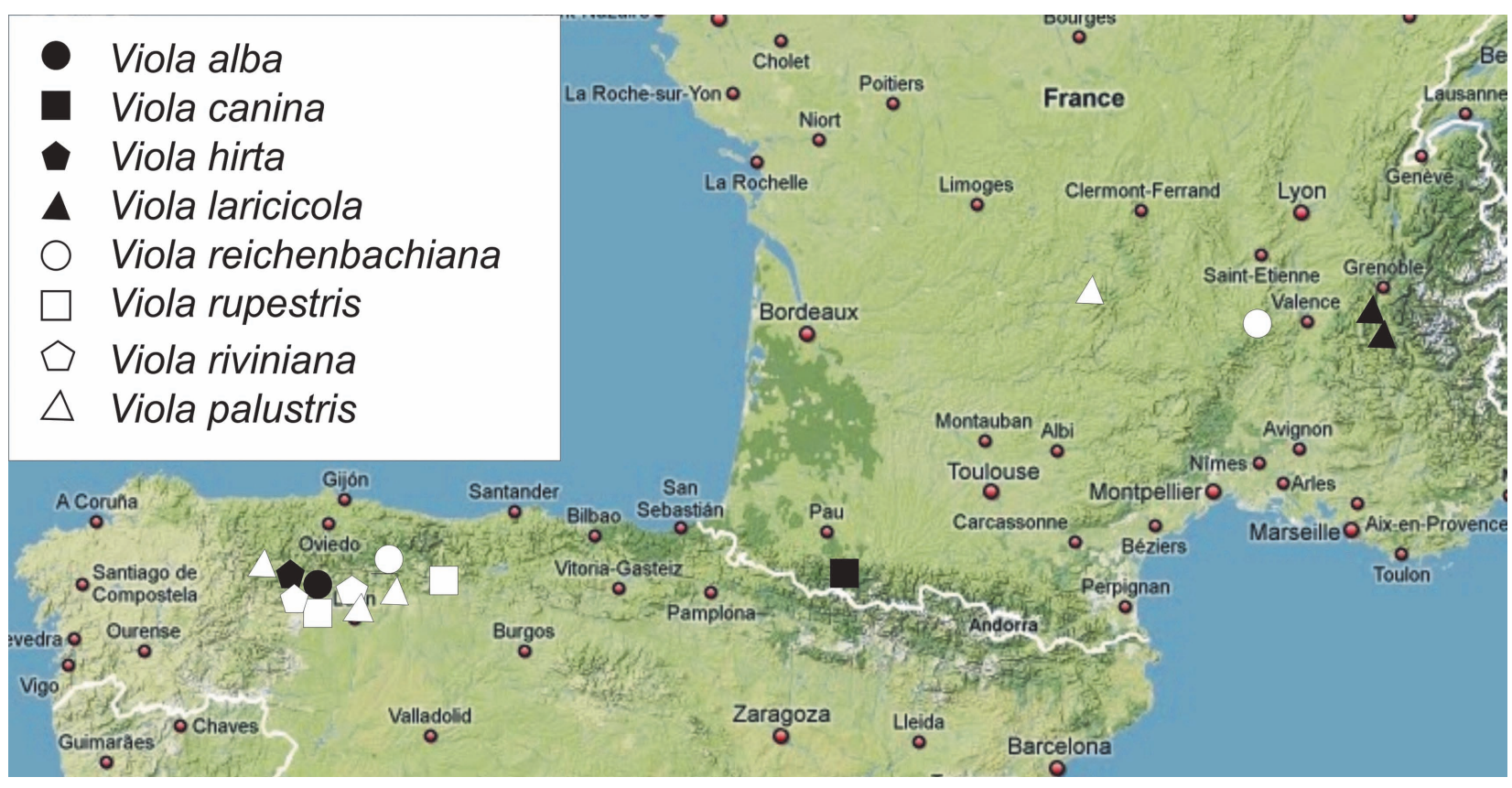

Fig. 1. Geographic distribution of the plants analysed in section Viola from genus Viola. 


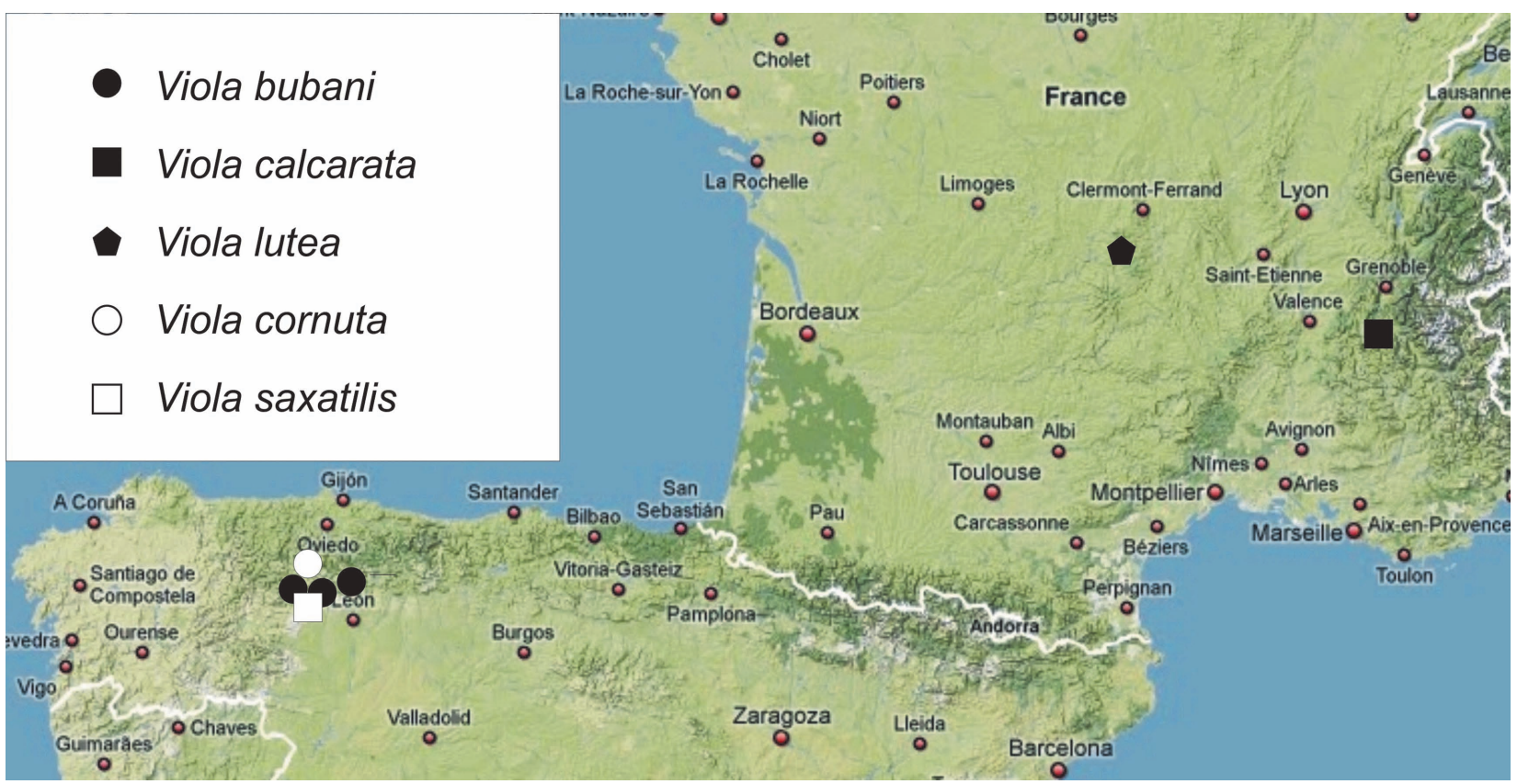

Fig. 2. Geographic distribution of the plants analysed in section Melanium from genus Viola.

num lycopersicum 'Stupicke' 2C $=1.96$ pg; Doležel \& al., 1992), maize (Zea mays CE-777 line 2C = 5.43 pg; Lysák \& Doležel, 1998) and pea (Pisum sativum 'Ctirad' 2C = 9.09 pg; Doležel \& al., 1998). These internal reference standards were provided by Prof. Jaroslav Doležel, Laboratory of Molecular Cytogenetics and Cytometry, Institute of Experimental Botany, Olomouc, Czech Republic.

To release plant nuclei from Viola species, tissues from leaves, leaf petioles and flowers were used. Preliminary experiments tested four nuclear isolation buffers: LB01 [15 mM Tris, 2 mM Na EDTA, $_{2}$. $5 \mathrm{mM}$ spermine tetrahydrochloride, $80 \mathrm{mM} \mathrm{KCl}, 20 \mathrm{mM}$ $\mathrm{NaCl}, 15 \mathrm{mM}$ ß-mercaptoethanol, 0.1\% (v/v) Triton X-100, pH 7.5] (Doležel \& al., 1989); Otto's [Otto I: $100 \mathrm{mM}$ citric acid monohydrate, $0.5 \%$ (v/v) Tween 20 (pH approx. 2-3); Otto II: $400 \mathrm{mM}$ $\mathrm{Na}_{2} \mathrm{HPO}_{4} \cdot 12 \mathrm{H}_{2} \mathrm{O}$ (pH approx. 8-9)] (Otto, 1990; Doležel \& Göhde, 1995); and Tris. $\mathrm{MgCl}_{2}$ [200 mM Tris, $4 \mathrm{mM} \mathrm{MgCl}_{2} \cdot 6 \mathrm{H}_{2} \mathrm{O}, 0.5 \%(\mathrm{v} / \mathrm{v})$ Triton X- 100, $\mathrm{pH}$ 7.5] (Pfosser \& al., 1995). Additionally, we also tested Tris. $\mathrm{MgCl}_{2}$ lysis buffer supplemented with PVP-10, to a final chemical composition of $200 \mathrm{mM}$ Tris, $4 \mathrm{mM} \mathrm{MgCl}_{2} \cdot 6 \mathrm{H}_{2} \mathrm{O}, 0.5 \%$ (v/v) Triton X-100, $1 \%(\mathrm{w} / \mathrm{v}) \mathrm{PVP}-10, \mathrm{pH}$ 7.5. This buffer, recommended by Loureiro \& al. (2007b) for mucilaginous species, contains a higher detergent concentration than standard Tris. $\mathrm{MgCl}_{2}$ buffer, which is important in reducing sample viscosity and minimizing the negative effect of mucilaginous compounds. From all these buffers, LB01 and Tris. $\mathrm{MgCl}_{2}+$ PVP-10 were selected for their superior results with the majority of Viola species used in the assays.

Nuclear suspensions were obtained following the protocol developed by Galbraith \& al. (1983). Plant tissues of the problem species (the weight depended on the type of plant material and the protocol used, see explanation in Fig. 3) and 50-150 mg of internal reference standard were chopped with a sharp scalpel in a glass Petri dish containing $1 \mathrm{~mL}$ of LB01 lysis (Doležel \& al., 1989) or Tris. $\mathrm{MgCl}_{2}+$ PVP-10 buffer (Loureiro \& al., 2007b). Different strategies were employed during the processing of samples in order to obtain high-quality histograms (see details in Fig. 3). A column of cosmetic cotton made of $100 \%$ cotton was used for nuclei filtration. The cotton ball filters were cut into $5 \times 1$-cm pieces, moistened with LB01 or Tris. $\mathrm{MgCl}_{2}+$ PVP-10 buffer, and loosely rolled into a cylindrical shape. The cotton balls were gently inserted into the middle of a 1-mL pipette tip to remove floating cotton fibers. The cotton ball filters out the particles on the basis of differences in their physical structure, and the position of the cotton ball affects both the efficiency of filtration and the yield of nuclei. We increased the amount of tissue used for extraction of nuclei when using cotton ball filters, as the nuclei yield is reduced using this filtration process. Leaf samples were also used as controls, with no filtration process. 


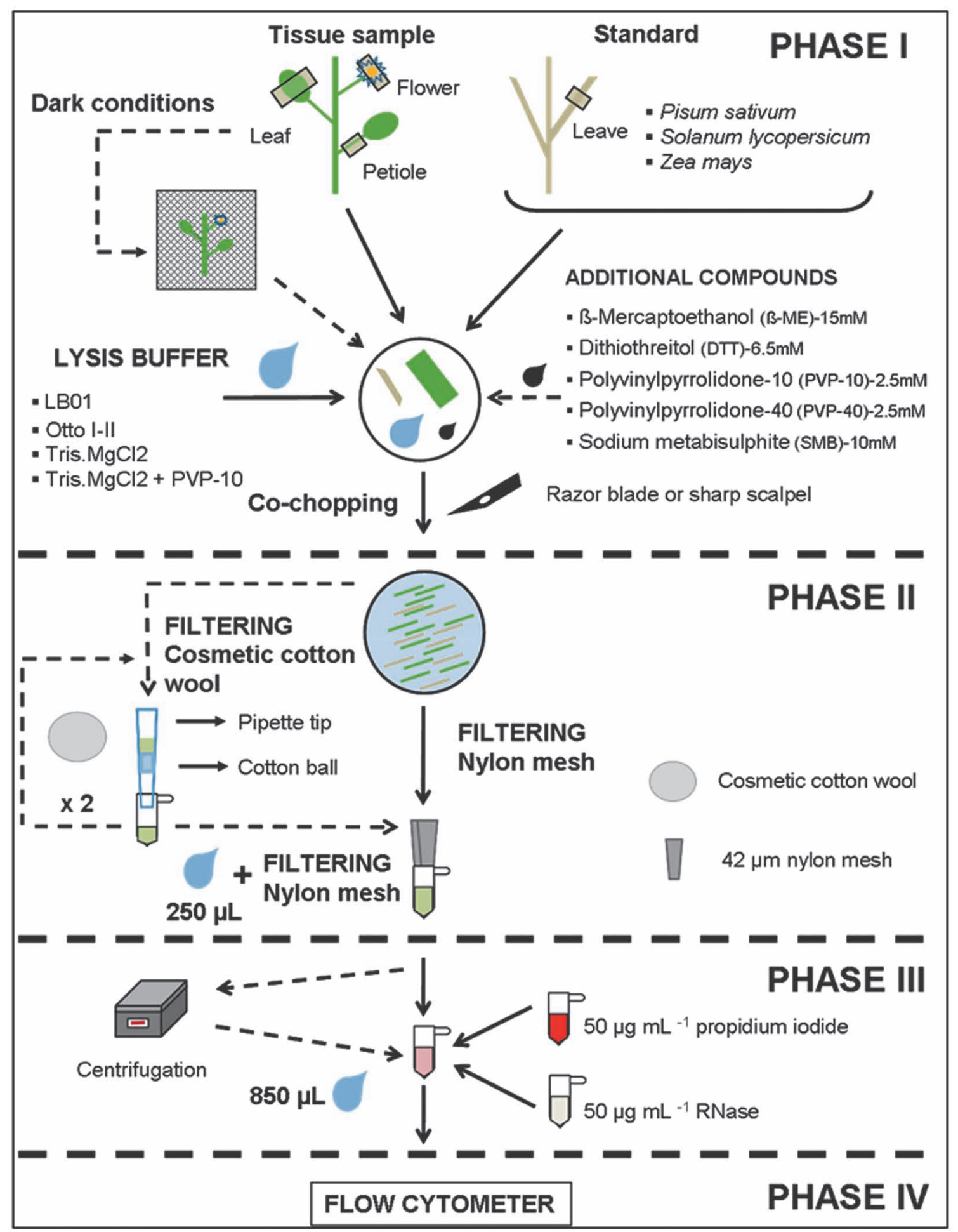

Phase I. Preparation of nuclear suspension. Place a small amount of plant tissue (50 $\mathrm{mg}$ if filtering with nylon mesh and $150 \mathrm{mg}$ if filtering with cosmetic cotton wool) and internal reference standard in the centre of a plastic Petri dish. Add $1 \mathrm{~mL}$ ice-cold nuclei isolation buffer ( $\left(\mathrm{BB} 01, \mathrm{Otto}\right.$ 's buffer, Tris. $\mathrm{MgCl}_{2}$ or Tris.MgCl $\left.2+\mathrm{PVP}-10\right)$. Compound antioxidants such as B-ME, DTT, PVP-10 PVP-40 and SMB can be added. FCM in plants after a period of darkness at $4{ }^{\circ} \mathrm{C}$ was also tested. Then, immediately chop the tissue in the buffer with a new razor blade or a sharp (disposable) scalpel. Phase II. Filter the homogenate using one-step protocol (filtering with nylon mesh) or two-step protocol (filtering with cosmetic cotton wool and nylon mesh). Insert the cotton wool ball into a 1-mL pipette tip to form a filtration column, and then add $250 \mu \mathrm{L}$ of nuclei isolation buffer. Leave in the buffer for a 15 -min incubation period before filtering to reduce the viscosity. Next, filter the homogenate through a 42 -mm nylon mesh into a labelled collection tube. Phase III. Addition of a stock solution of a DNA fluorochrome. Add propidium iodide $\left(50 \mu \mathrm{g} \mathrm{mL}^{-1}\right)$ simultaneously with RNase $\left(50 \mu \mathrm{g} \mathrm{mL}{ }^{-1}\right)$ and shake gently. Optionally, the homogenate can be centrifuged at $120 \mathrm{~g}$ for $10 \mathrm{~min}$. at $4^{\circ} \mathrm{C}$. The supernatant is then carefully decanted (to remove $750 \mu \mathrm{L}$ ), and the pellet gently resuspended in $850 \mu \mathrm{L}$ of new extraction buffer. Incubate the samples in the dark, for $15 \mathrm{~min}$ at $4{ }^{\circ} \mathrm{C}$, before flow cytometric analysis. Phase IV. Analysis of nuclear DNA content. Introduce the suspension of stained nuclei into the flow cytometer.

Fig. 3. Procedure for preparing suspensions of intact nuclei in several species of genus Viola. Dashed lines indicate optional steps. 


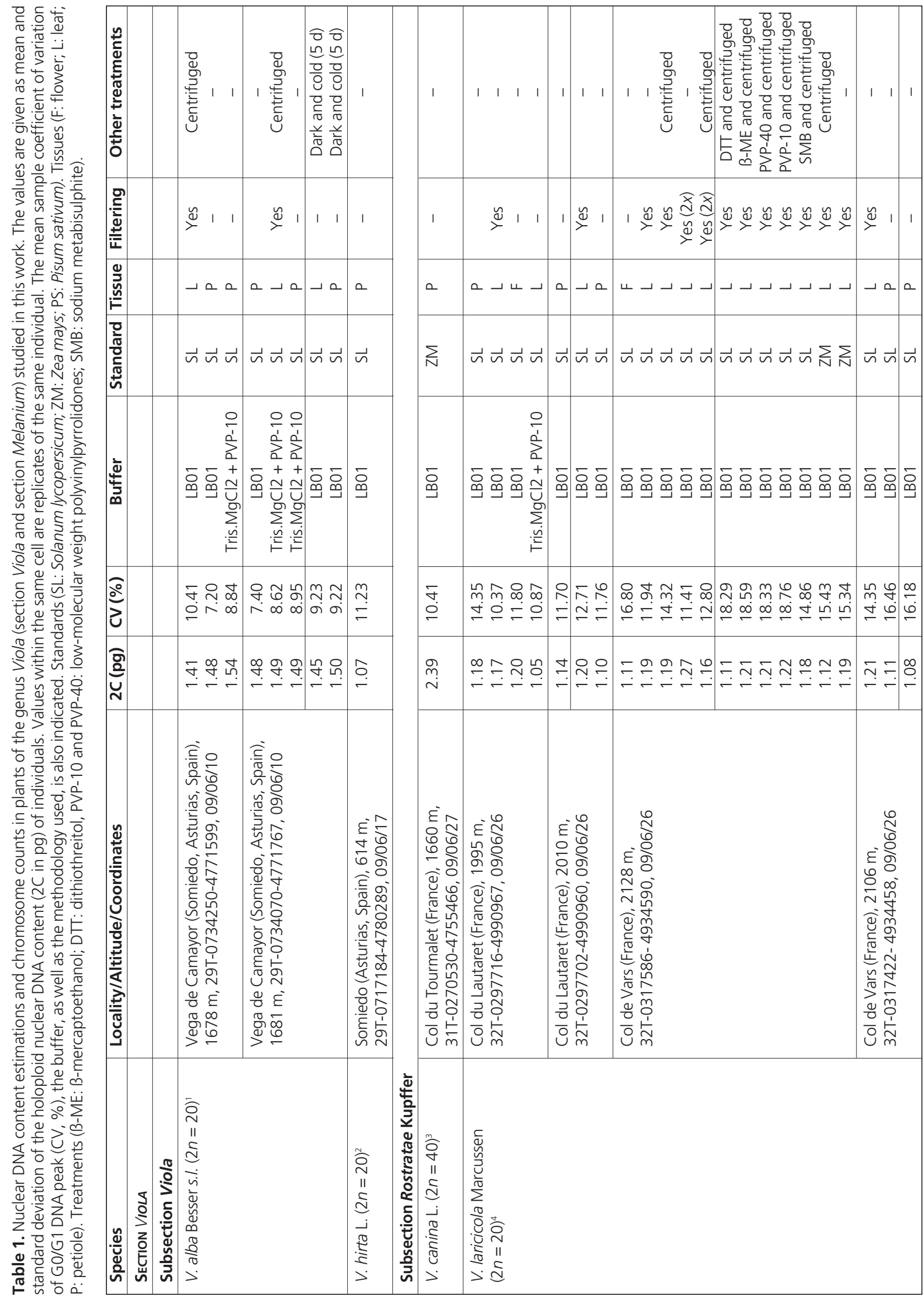




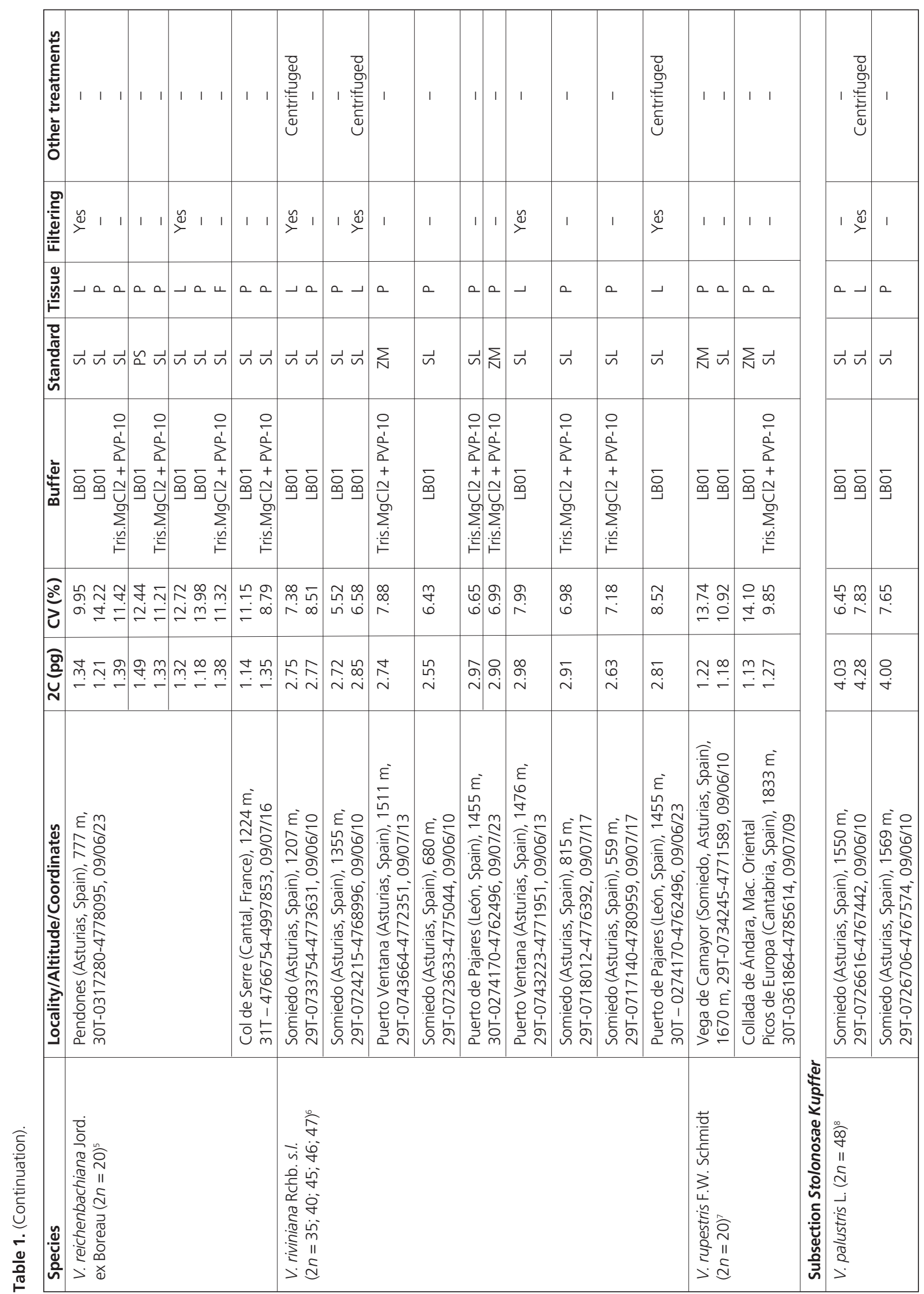




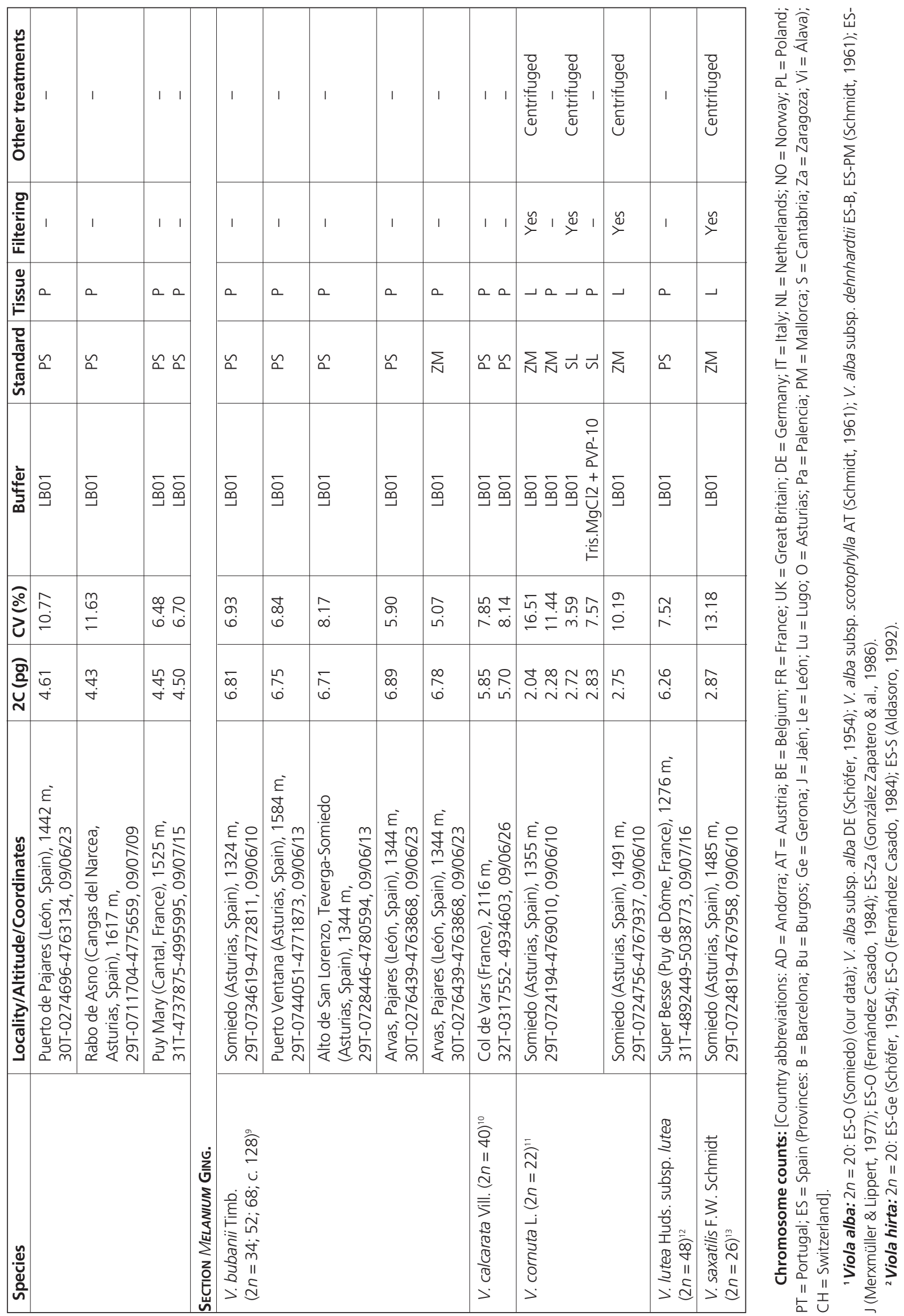




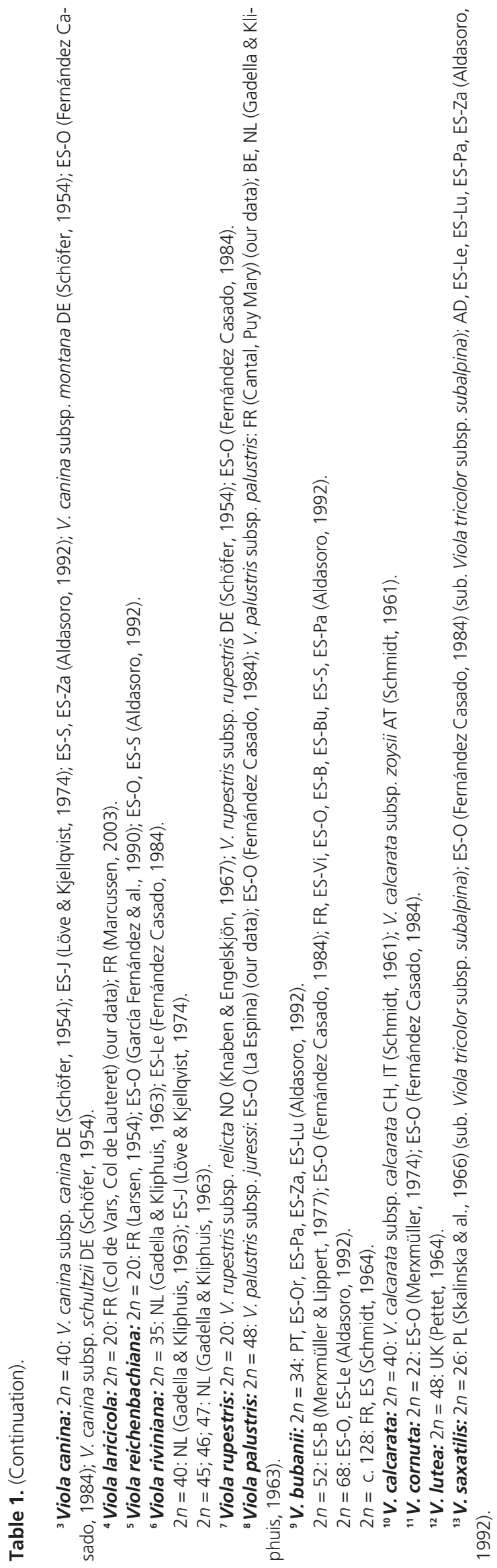

In addition, antioxidants such as $ß$-mercaptoethanol (ß-ME), dithiothreitol (DTT), sodium metabisulphite (SMB) and low-molecular weight polyvinylpyrrolidones (PVPs), such as PVP-10 and PVP-40, were also added to the isolation buffer to improve the quality and fluorescent intensity of preparations. Some samples were also analysed after a 5 -day period in darkness at $4{ }^{\circ} \mathrm{C}$, to check the possible effect of darkness on reducing the viscosity of the samples and its effect on the quality of the histograms.

To minimize the release of cytosolic compounds, chopping was quick (about $45 \mathrm{sec}$ ) and not very intense, and a 15-min incubation period in the buffer before filtration was necessary to reduce the viscosity of the sample and increase nuclei yield (a modification of Loureiro \& al., 2007b). The nuclear suspension was filtered through a $42 \mu \mathrm{m}$ nylon mesh and nuclei were stained with $50 \mu \mathrm{g} \mathrm{mL}^{-1}$ propidium iodide (PI, Sigma). Also, $50 \mu \mathrm{g} \mathrm{mL}{ }^{-1}$ RNase (Sigma) was added to the nuclear homogenate to avoid PI staining of double stranded RNA. Samples were kept on ice throughout the process and analysed, after an additional 15-min incubation period, using a Cytomics FC 500 (Beckman Coulter) with 488-nm excitation from an argon ion laser. Data analysis was carried out using Cytomics RXP Analysis (Beckman Coulter, Inc. 2006). At least three replicates were performed per species on three different days in order to avoid the effect of instrument fluctuations.

The holoploid genome size (2C; sensu Greilhuber $\&$ al., 2005) of Viola species was estimated according to the following formula:

$$
\begin{aligned}
& \frac{2 \mathrm{C} \text { nuclear DNA content }(\mathrm{pg})=}{\text { Viola } \mathrm{sp} . \mathrm{G} 0 / \mathrm{G} 1 \text { peak mean }} \\
\text { reference standard G0k/G1 peak mean } & \begin{array}{c}
\text { nuclear DNA content of } \\
\text { reference standard }
\end{array}
\end{aligned}
$$

Genome size data were analysed using a one-way ANOVA on ranks, and the Dunn's method was applied for pair-wise comparison (SigmaStat for Windows Version 3.1, SPSS Inc., USA).

\section{Results}

A first study was developed in leaf tissue of different species of Viola using Otto's buffers (the same buffer employed in previous studies; i.e. Suda $\&$ al., 2005; Hodálová \& al., 2008; Mered'a \& al., 2008). The samples were simply filtered through a nylon mesh of $42 \mu \mathrm{m}$ but the contaminants that cannot be removed probably interfered with peaks and led us to an incorrect determination of nuclear DNA content. Due to a pronounced slime production, the FCM signal was not detected in the samples prepared from leaf laminas. The quality of histograms obtained 
was discouraging, since, just like other researchers results were completely masked by the presence of slime (Pavol Mered'a, Institute of Botany, Slovak Academy of Sciences, Slovak Republic; pers. comm.).

Nuclear DNA content estimations for each species with the different treatments and chromosome counts are presented in Table 1 . These data are presented following the systematics relating to sections and subsections of this genus. The mean value genome size of $V$. alba Besser was estimated as $1.48 \pm 0.037 \mathrm{pg} / 2 \mathrm{C}$; of $V$. bubanii Timb.-Lagr. as $6.78 \pm 0.068 \mathrm{pg} / 2 \mathrm{C}$; of $V$. calcarata L. as $5.77 \pm 0.106 \mathrm{pg} / 2 \mathrm{C}$; of $V$. canina L. as $2.39 \mathrm{pg} / 2 \mathrm{C}$; of $V$. cornuta L. as $2.52 \pm 0.345 \mathrm{pg} / 2 \mathrm{C}$; of $V$. hirta L. as $1.07 \mathrm{pg} / 2 \mathrm{C}$; of $V$. laricicola Marcussen as $1.16 \pm 0.054 \mathrm{pg} / 2 \mathrm{C}$; of $\mathrm{V}$. lutea Huds. subsp. lutea as $6.26 \mathrm{pg} / 2 \mathrm{C}$; of V.palustris L. as $4.32 \pm 0.236 \mathrm{pg} / 2 \mathrm{C}$; of $V$. reichenbachiana Jord. ex Boreau as $1.33 \pm 0.099$ $\mathrm{pg} / 2 \mathrm{C}$; of $V$. riviniana $\mathrm{Rchb}$. as $2.79 \pm 0.132 \mathrm{pg} / 2 \mathrm{C}$; of $V$. rupestris F.W. Schmidt as $1.20 \pm 0.059 \mathrm{pg} / 2 \mathrm{C}$ and finally of $V$. saxatilis F.W. Schmidt as $2.87 \mathrm{pg} / 2 \mathrm{C}$
(Table 1, Figs. 4, 5). Statistical analyses revealed significant differences between the section Viola and section Melanium as well as statistically significant differences within each subsection $(\mathrm{P}<0.001)$. The large differences in values (pg) among the subsections studied indicate possible genome size variation within this genus, being consistent with chromosome counts. Statistically significant differences were not detected between samples of the same species. A comparison of the present results with the few previous determinations for the genus Viola (Grime \& al., 1985; Suda $\&$ al., 2005), shows that our data are very similar (Table 1), despite the high CV and the quality assessment given by the DNA index (DI, ratio between the mean channel position of sample and standard G0/G1 peaks) of peaks. Finally, our results demonstrate that the use of antioxidant compounds and/or absolute darkness conditions did not improve the quality of the histograms (Table 1), and sometimes even masked the results (data not shown).
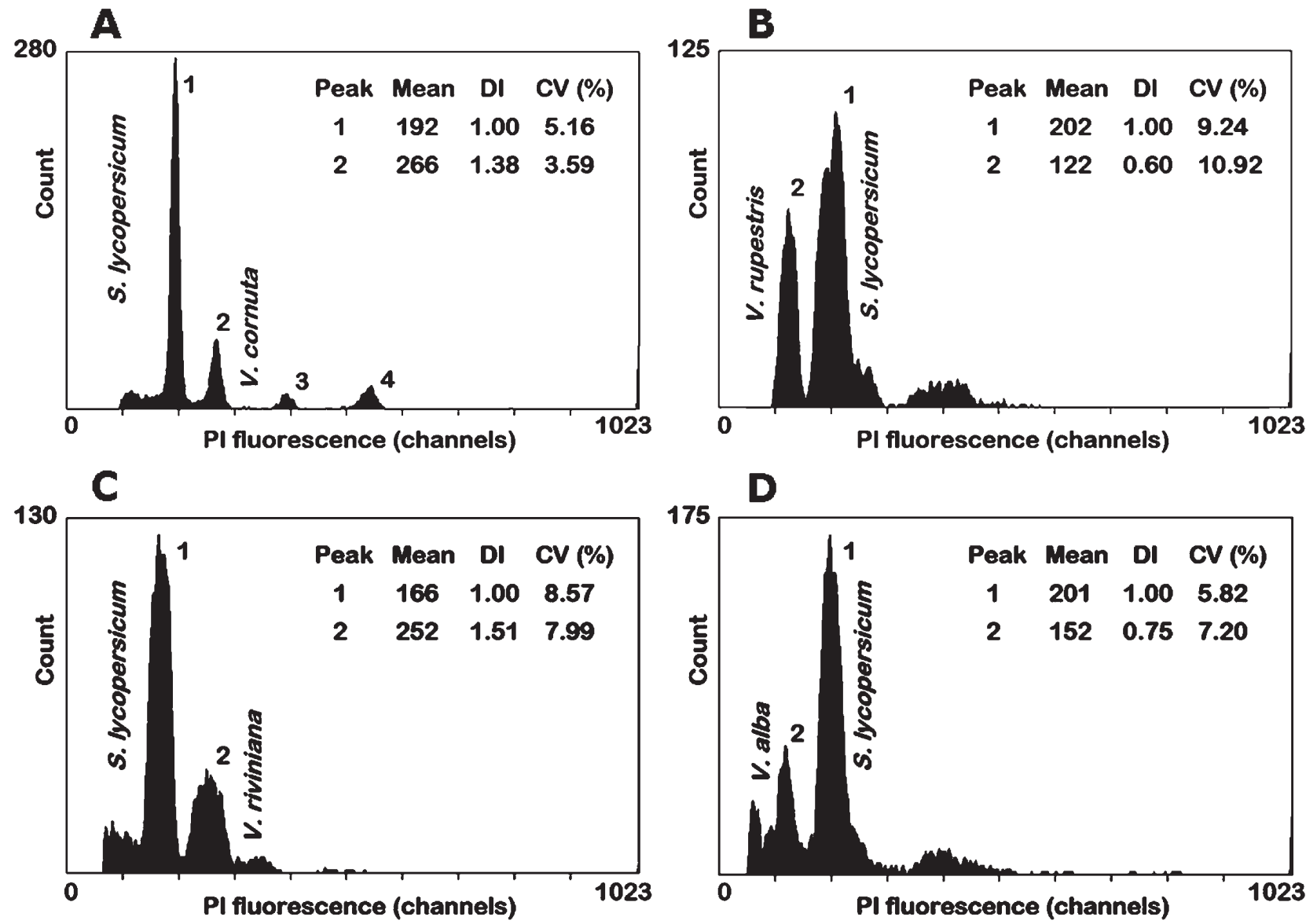

Fig. 4. Flow cytometric histograms obtained for different species of Viola. The peaks marked with 1 and 2 indicate nuclei at the G0/G1 phase of the internal standard and the G0/G1 phase of the sample, respectively. The mean channel number (PI fluorescence), DNA in$\operatorname{dex}(\mathrm{DI}=$ mean channel number of sample/mean channel number of reference standard) and coefficient of variation value (CV, \%) of each peak are also given. Numbers 3 and 4 correspond to G2/M peaks of the internal standard and of the sample, respectively. 


\section{Discussion}

\section{About the protocol}

The protocol presented here shows great potential for its application in the estimation of genome size of species with similar problems. Despite the high variation of CVs, all replicates made in the present study show similar values with respect to the amount of DNA. However, further research still needs to be carried out with the aim of reducing the $\mathrm{CV}$ obtained. As has been described for the analyses of old herbarium vouchers or tiny silica samples (Suda \& Trávníček, 2006), where not all requirements on peak quality, such as $C V$ values and number of nuclei, achieve the same levels as when using fresh plant material, our results lead us to state that mucilaginous tissue requirements should be evaluated in each specific case. For example, collection of fluorescence intensities for 5000 nuclei may not be possible. Nevertheless, a smaller number of nuclei (e.g., 1000 to 3000) may still yield useful information, particularly if the screening for differences in ploidy level is the main concern. According to Doležel \& Bartoš (2005), the CV of DNA peaks quantifies the precision of individual measurements but says nothing about the reproducibility of DNA content estimation. Therefore, guidelines for peak CVs, replication within individuals, and similarity in DNA content of the target species and the standard, all depend on the importance of distinguishing small differences in DNA content. For differences on the scale of whole sets of chromosomes, $\mathrm{CV}$ values around $10 \%$ are a common consequence, and can be tolerated especially when using problematic tissues (Suda \& al., 2007). Furthermore, when fine scale distinctions are not required, the non-coincidence of results between replications is acceptable (Suda \& al., 2007). However, the use of cosmetic cotton wool ball filters to form a mesh network that inhibits the passage of irregularly shaped contaminants leads to an improvement in CV (at least in leaf material). The cosmetic cotton wool ball filters have already been successfully used with mature orchid leaves to remove calcium oxalate crystals (Lee \& Lin, 2005).

\section{Section Viola}

In subsection Viola of section Viola, according to our counts in the radicular apices, the samples from $V$. alba (1.41-1.54 pg) are characterized by the chromosome number of $2 n=20$. Several authors have described the same chromosome number in V. alba s.l. from European and Spanish localities: V. alba subsp. alba in Germany (Schöfer, 1954) and Romania (Mered'a \& al., 2008); V. alba subsp. scotophylla (Jord.)
Nyman in Austria (Schmidt, 1961); and V. alba subsp. debnhardtii (Ten.) W. Becker in the Spanish localities of Barcelona (Schmidt, 1961), Asturias (Fernández Casado, 1984), Zaragoza (González Zapatero \& al., 1986), Jaén (Merxmüller \& Lippert, 1977) and Mallorca (Schmidt, 1961). It is worth noting the treatment of the problems associated with these plant groups in the Cantabrian Mountains (Laínz, 1962, 1967; Montserrat, 1992), and additionally, the lack of the presence of $V$. alba in Cantabria and in the western part of the Cantabrian Mountains (Muñoz Garmendia \& al., 1993). With reference to $V$. birta, the DNA content of the single analysed sample (1.07 pg) seems to be consistent with the chromosome number described for this species $(2 n=20)$, counted in plants from Germany (Schöfer, 1954), Slovakia (Mered'a \& al., 2006), Ukraine and Romania (Mered'a \& al., 2008) and, within Spain, in Asturias (Fernández Casado, 1984) and Cantabria (Aldasoro, 1992).

In subsection Rostratae of the section Viola, samples from 5 different species were analysed: $V$. canina, $V$. laricicola, $V$. reichenbachiana, $V$. riviniana and $V$. rupestris. The 2C-value was measured in one sample of $V$. canina $(2.39 \mathrm{pg})$, a result consistent with a chromosome number $(2 n=40)$ described in plants of different subspecies of $V$. canina such as: $V$. canina subsp. canina from Germany (Schöfer, 1954) and, in Spain, from Jaén (Löve \& Kjellqvist, 1974), Asturias, Cantabria and Zamora (Aldasoro, 1992); V. canina subsp. montana (L.) Hartm. from Germany (Schöfer, 1954) and, in Spain, from Asturias (Fernández Casado, 1984); and finally V. canina subsp. schultzii (Billot) Kirschl. from Germany (Schöfer, 1954).

DNA measurements of many samples from the alpine endemic $V$. laricicola (1.05-1.27 pg) seem to be consistent with the chromosome number of samples of the same species belonging to Col de Vars and Col du Lautaret (France): $2 n=20$ (our data and those from Marcussen, 2003). We would also like to highlight that this species was collected in siliceous substrates (Fig. 5A), not in limestone as Marcussen (2003) indicates in his description.

Additionally, DNA measurements of those samples identified as $V$. reichenbachiana $(1.18-1.49 \mathrm{pg})$ support the chromosome count of $2 n=20$ for plants of this species from many different territories: France (Larsen, 1954), Slovakia (Mered'a \& al., 2006), Finland (Stork, 1971), and Spain, more specifically in Asturias (García Fernández \& al., 1990; Laínz, 1992; Aldasoro, 1992) and Cantabria (Aldasoro, 1992; Laínz, 1992).

Those plants identified as $V$. riviniana showed DNA content ranging from 2.55 to $2.98 \mathrm{pg}$; matching 
the data obtained by Grime \& al. (1985): 2.70 pg. Previous chromosome counts have reported diverse results: $2 n=40$ from Denmark (Clausen, 1927), $2 n=35$, 40, 45, 46 and 47 from Holland (Gadella \& Kliphuis, 1963); $2 n=30$ and $2 n=c .40$ from Finland (Harmaja, 2003); $2 n=40$ from Slovakia (Mered'a \& al., 2006), $2 n=36,40$ and 42 from France (Dizerbo, 1972), $2 n=40$ and 46 from England (Valentine, 1941); and from Spain $2 n=35$ in León (Fernández Casado, 1984); $2 n=40$ in Jaén (Löve \& Kjellqvist, 1974) and in Almería, Asturias, Ávila, Cantabria, Salamanca and Zamora (Aldasoro, 1992). In numerous plants from
Asturias identified as V. riviniana (García Fernández $\&$ al., 1990) the most frequent chromosome numbers reported were $2 n=35$ and 40 , though the less frequent count of $2 n=30$ was also identified. This count of $2 n=30$ was also detected in Slovakia (Mered'a \& al., 2006), corresponding to $V . \times$ bavarica Schrank $(V$. reichenbachiana $\times V$. riviniana). Therefore, the DNA amount data of samples from $V$. riviniana established in the present work fit within the diverse data found for this species.

In the case of $V$. rupestris, the published chromosome count is $2 n=20$, both in the Norwegian samples

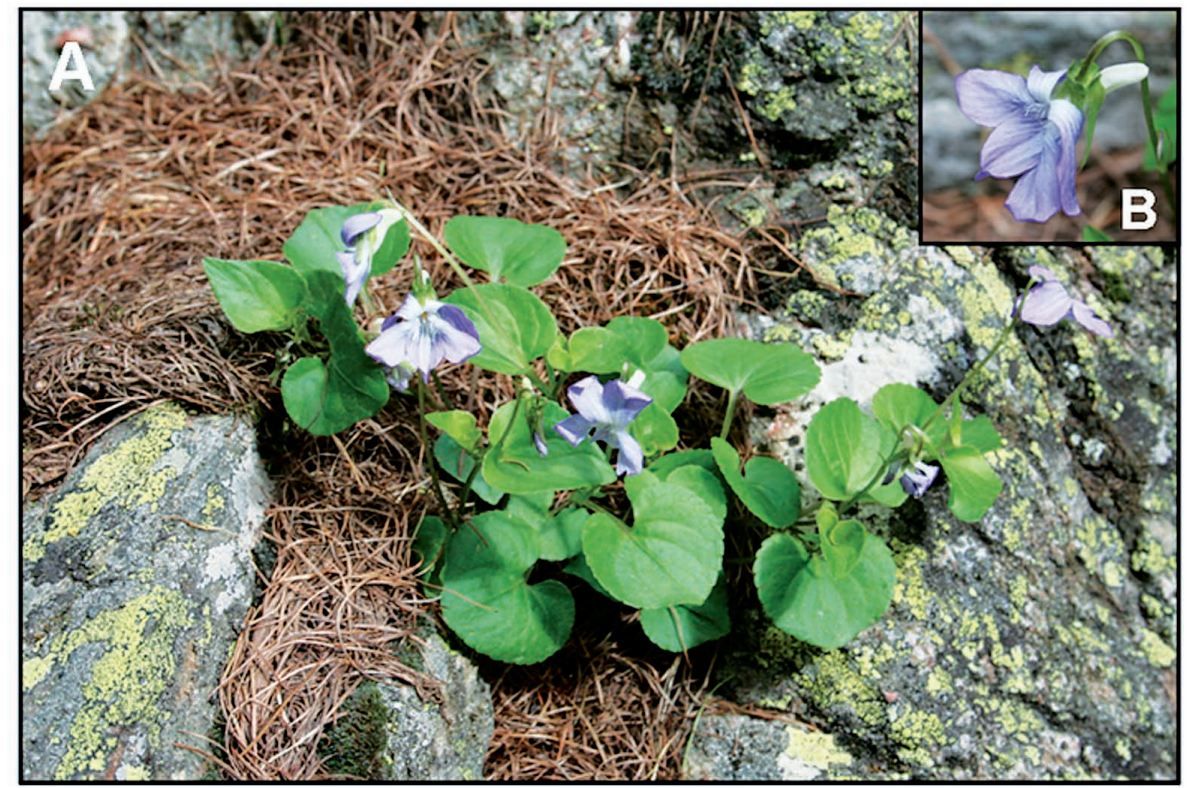

C

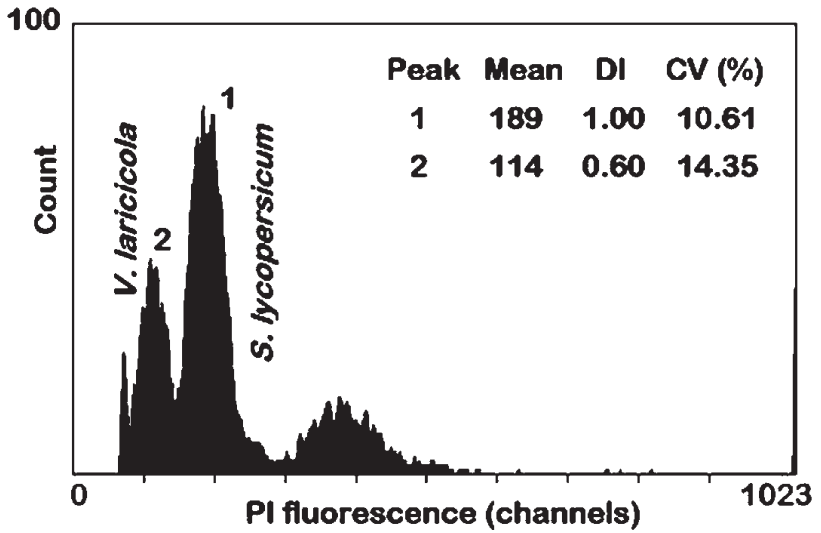

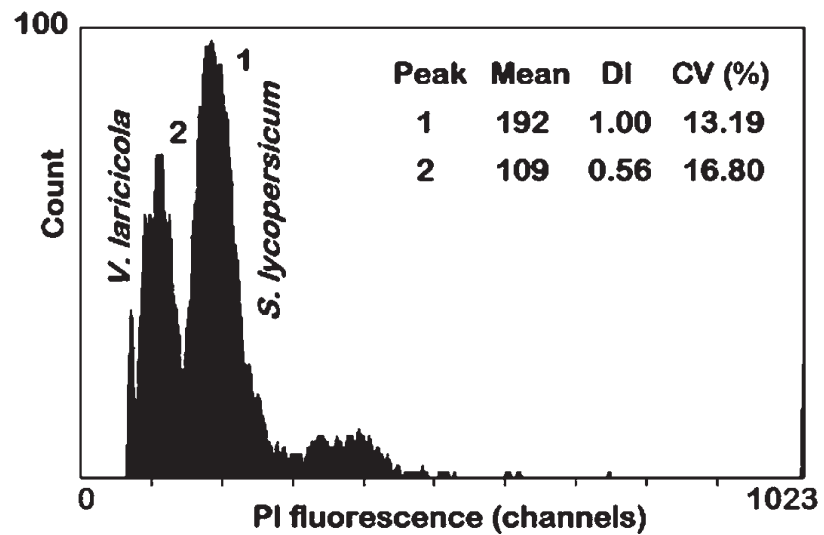

The peaks marked with 1 and 2 indicate nuclei at the G0/G1 phase of the internal standard and the G0/G1 phase of the sample, respectively. The mean channel number (PI fluorescence), DNA index (DI = mean channel number of sample/mean channel number of reference standard) and coefficient of variation value $(\mathrm{CV}, \%)$ of each peak are also given.

Fig. 5. Viola laricicola, alpine endemism: A, general appearance between blocks of siliceous substrate (silicate-dwelling); $\mathbf{B}$, flower detail with white spur; C, histogram obtained from the population of Col du Lautaret; D, histogram obtained from the population of Col de Vars. 
of $V$. rupestris subsp. relicta Jalas (Knaben \& Engelskjön, 1967), and the German samples of V.rupestris subsp. rupestris (Schöfer, 1954). The same result was obtained in samples of $V$. rupestris subsp. rupestris from Asturias (Fernández Casado, 1984). These results are consistent with the DNA estimations for the plants of this species (1.13-1.27 pg) within this study.

The DNA measurements from the species of subsection Stolonosae (section Viola) studied in the present work, V. palustris, ranged from 4.00 to $4.61 \mathrm{pg}$. In this species, the chromosome count described for $V$. palustris subsp. palustris in Belgium and Holland (Gadella \& Kliphuis, 1963) and Poland (Kuta, 1990) is $2 n=48$; we obtained the same value for the sample from Puy Mary (France). In the Asturian plant identified as V. palustris subsp. juressi (Link ex Wein) Cout., Fernández Casado (1984) also found $2 n=48$ chromosomes.

\section{Section Melanium}

In section Melanium of genus Viola, samples from 5 different taxa were analysed: $V$. bubanii, $V$. calcarata, $V$. cornuta, $V$. lutea subsp. lutea and $V$. saxatilis. In the Pyrenean-Cantabrian endemic $V$. bubanii, the genome size data were quite similar in all the samples analysed, that is, between 6.71 and $6.89 \mathrm{pg}$. Chromosome counts of the same species, including samples from the same central-western Cantabrian sampling localities were: i.e. $2 n=c .128$ in the Pyrenees by Schmidt (1964) and Merxmüller (1974), results which have never been reproduced; and more frequently, $2 n=52$, both in the Pyrenees (Merxmüller \& Lippert, 1977; Aldasoro, 1992) and in the Cantabrian Mountains in Asturias (Fernández Casado, 1984; Aldasoro, 1992), Álava, Burgos, Cantabria and Palencia (Aldasoro, 1992). This last author (Aldasoro, 1992) obtained counts of $2 n=34$ in plants of this same species from Orense, $\mathrm{Pa}-$ lencia, Zamora (all in Spain) and Tras-os-Montes (Portugal), and counts of $2 n=68$ in Cantabrian plants from the area of Puerto de Pajares (Asturias-León). It is likely that the DNA data of the plants analysed in this study correspond to plants of $2 n=52$.

The single alpine plant analysed of $V$. calcarata showed a 2C-value of 5.70-5.85 pg. All previous chromosome counts of this species were $2 n=40$, both in $V$. calcarata subsp. calcarata from Switzerland and Italy (Schmidt, 1961), and in V. calcarata subsp. zoysii (Wulfen) Merxm. from Austria (Schmidt, 1961).

The 2C-value of Cantabrian samples from V. cornuta ranged from 2.04 to $2.83 \mathrm{pg}$, and the chromosome counts registered $2 n=22$, not only in plants from Asturias (Merxmüller, 1974; Fernández Casado, 1984) but also those from other provenances (Clausen, 1927; Griesinger, 1937).

The unique sample analysed of $V$. lutea subsp. lutea showed a $2 \mathrm{C}$-value of $6.26 \mathrm{pg}$, a value close to that to be expected, considering the chromosome count of $2 n=48$ in plants from Great Britain (Pettet, 1964).

Finally, the value for $V$. saxatilis $(=V$. tricolor $\mathrm{L}$. subsp. subalpina Gaudin) was 2.87 pg from the Cantabrian sample, which belonged to the same locality of a previous chromosome counting (Fernández Casado, 1984); the chromosome number described for this taxon $(2 n=26)$, was consistent with the value determined in samples from Poland (Skalinska \& al., 1966), Andorra (Aldasoro, 1992) and diverse localities, both Pyrenean (Lérida; Aldadoro, 1992) and Cantabrian (León, Palencia and Zamora; Aldasoro, 1992).

\section{Conclusion}

We are aware that a single reliable $\mathrm{C}$-value should be established using a method yielding absolute amounts of DNA for each plant standard. This is a sensitive point, because in fact only one $\mathrm{C}$-value is generally accepted. However, FCM research to uncover the effects of secondary metabolites on measurement results has begun only recently and should be one of the priority areas for future research (Greilhuber, 2008).

We believe that future research should focus on ways of reducing $\mathrm{CV}$ and some lines of investigation might be:

I) The use of other isolation and/or staining buffer(s). The different buffer characteristics and the cytosolic compounds released upon chopping up the tissue can affect sample and measurement quality. Comparative analyses of buffers are therefore required, though such studies have seldom been undertaken (Greilhuber \& al., 2007). Cytosolic compounds can have a profound effect on genome size estimations, leading not only to the false identification of intraspecific variation, but also to erroneous determinations of absolute genome size. Investigations into the diversity and mode of action of such compounds are still at an early stage but their potential presence and effect is something to which researchers should always be alert (Leitch \& Bennett, 2007). The use of different buffers, such as woody plant buffer (WPB; Loureiro \& al., 2007a), Galbraith's buffer (Galbraith $\&$ al., 1983), etc. or even the generation of new buffers specifically for highly viscous samples with the intention of getting clearer peaks and high fluorescence stability, should be investigated.

II) Inclusion of antioxidants or chemical compounds which preserve the nuclei integrity 
(e.g. ß-ME, DTT, SMB, PVPs, etc.). It is obvious that the content of detergent, reductants, polyvinylpyrrolidone (PVP) and chromatin stabilizers (such as spermine or magnesium ions) can influence the quality of measurements; however, we found no improvement in the quality of the histograms attributable to the adding of different antioxidants or the centrifugeresuspend to the different samples of Viola (see Table 1).

III) Selection of different plant tissues with the lowest viscosity (leaf petioles, young stems, cotyledons, inflorescence axes, dry seeds, etc.). Nuclear DNA estimations of Viola were done using the leaves, flowers and petioles, providing similar results and the first data on the genome size of the group.

\section{Acknowledgements}

We acknowledge the technical assistance of Ana Salas and Marta Alonso Guervós (Flow Cytometry Area, Scientific-Technical Services, University of Oviedo). We express our gratitude to Dr Pavol Mered'a (Institute of Botany, Slovak Academy of Sciences, Bratislava, Slovak Republic) for his comments and Dr J. Doležel (Laboratory of Molecular Cytogenetics and Cytometry, Institute of Experimental Botany, Olomouc, Czech Republic) for providing the internal reference standards.

\section{References}

Ajalin, I., Kobza, F. \& Doležel, J. 2002. Ploidy identification of doubled chromosome number plants in Viola $\times$ wittrockiana Gams. M 1-generation. Hortscience 29: 35-40.

Aldasoro, J.J. 1992. Números cromosomáticos de plantas occidentales, 668-680. Anales del Jardín Botánico de Madrid 50(2): 247249.

Ballard, H.E., Sytsma, K.J. \& Kowal, R.R. 1999. Shrinking the violets: phylogenetic relationships of infrageneric groups in Viola (Violaceae) based on internal transcribed spacer DNA sequences. Systematic Botany 23: 439-458.

Becker, W. 1910a. Violenstudien I. Beihefte zum Botanischen Centralblatt 26: 1-44.

Becker, W. 1910b. Violenstudien II. Beihefte zum Botanischen Centralblatt 26: 289-390.

Becker, W. 1925. Viola L. In: Engler, A. \& Prantl, K. (eds.), Die natürlichen Pflanzenfamilien, Vol. 21. Wilhelm Engelmann, Leipzig, 363-376.

Bennett, M.D. \& Leitch, I.J. 2005. Angiosperm DNA C-values database (release 4.0, Dec. 2005), http://www.kew.org/cvalues/ homepage.html (retrieved 07 Sept. 2009).

Castroviejo, S. \& Valdés-Bermejo, E. (eds.) 1991. Números cromosomáticos de plantas vasculares ibéricas. Archivos de Flora Ibérica 1: 1-202.

Clausen, J. 1927. Chromosome number and the relationship of species in the genus Viola. Annals of Botany 41: 677-714.

Dizerbo, A.H. 1972. Les Viola de la section Nomimium du Massif Armoricain. Bulletin de la Société Scientifique de Bretagne 47(34): 137-139.

Doležel, J. \& Bartoš, J. 2005. Plant DNA flow cytometry and estimation of nuclear genome size. Annals of Botany 95: 99-110.

Doležel, J., Binarová, P. \& Lucretti, S. 1989. Analysis of nuclear
DNA content in plant cells by flow cytometry. Biologia Plantarum 31(2): 113-120.

Doležel, J. \& Göhde, W. 1995. Sex determination in dioecious plants Melandrium album and M. rubrum using high-resolution flow cytometry. Cytometry 19: 103-106.

Doležel, J., Greilhuber, J., Lucretti, S., Meister, A., Lysák, M.A., Nardi, L. \& Obermayer, R. 1998. Plant genome size estimation by flow cytometry: inter-laboratory comparison. Annals of Botany 82 (suppl. A): 17-26.

Doležel, J., Greilhuber, J. \& Suda, J. 2007a. Estimation of nuclear DNA content in plants using flow cytometry. Nature Protocols 2(9): 2233-2244.

Doležel, J., Greilhuber, J. \& Suda, J. 2007b. Flow cytometry with plants: an overview. In: Doležel, J., Greilhuber, J. \& Suda, J. (eds.), Flow cytometry with plant cells. Analysis of genes, chromosomes and genomes. Wiley-VCH Verlag, Weinheim, 41-65.

Doležel, J., Sgorbati, S. \& Lucretti, S. 1992. Comparison of three DNA fluorochromes for flow cytometric estimation of nuclear DNA content in plants. Physiologia Plantarum 85: 625-631.

Erben, M. 1996. The significance of hybridization on the forming of species in the genus Viola. Bocconea 5: 113-118.

Fernández Casado, M.A. 1982. Revisión de las especies del género Viola L. en la Península Ibérica. PhD Thesis, Universidad de Oviedo, Oviedo.

Fernández Casado, M.A. 1984. Estudios sobre el género Viola L. en la Península Ibérica. I. Cariología. Fontqueria 5: 23-32.

Gadella, F. \& Kliphuis, E. 1963. Chromosome numbers of flowering plants in the Netherlands. Acta Botanica Neerlandica 12(2): 195-230.

Galbraith, D.W., Harkins, K.R., Maddox, J.M., Ayres, N.M., Sharma, D.P. \& Firoozabady, E. 1983. Rapid flow cytometric analysis of the cell cycle in intact plant tissues. Science 220: 1049-1051.

García Fernández, R., Fernández Casado, M.A. \& Nava, H.S. 1990. Viola gr. silvestris en Asturias. Anales del Jardín Botánico de Madrid 47(2): 339-348.

González Zapatero, M.A., Elena Roselló, J.A. \& Navarro Andrés, F. 1986. Estudios cariológicos en táxones del CW español pertenecientes a Quercetea ilicis. Lazaroa 9: 61-68.

Greilhuber, J. 1986. Severely distorted Feulgen DNA amounts in Pinus (Coniferophytina) after nonadditive fixations as a result of meristematic self-tanning with vacuole contents. Canadian Journal of Genetics and Cytology 28: 409-415.

Greilhuber, J. 2008. Cytochemistry and C-values: the less-wellknown world of nuclear DNA amounts. Annals of Botany 101: 791-804.

Greilhuber, J., Doležel, J., Lysák, M.A. \& Bennett, M.D. 2005. The origin, evolution and proposed stabilization of the terms 'genome size' and 'C-value' to describe nuclear DNA contents. Annals of Botany 95: 255-260.

Greilhuber, J., Temsch, E.M. \& Loureiro, J.C.M. 2007. Nuclear DNA content measurement. In: Doležel, J., Greilhuber, J. \& Suda, J. (eds.), Flow cytometry with plant cells. Analysis of genes, chromosomes and genomes. Wiley-VCH Verlag, Weinheim, 67-101.

Griesinger, R. 1937. Über hypo- und hyperdiploide Formen von Petunia, Hyoscyamus, Lamium und einige andere Chromosomenzählungen. Berichte der Deutschen Botanischen Gesellschaft 55: 556-571.

Grime, J.P., Shacklock, J.M.L. \& Band, S.R. 1985. Nuclear DNA contents, shoot phenology and species co-existence in a limestone grassland community. New Phytologist 100: 435-445. 
Harmaja, H. 2003. A deviating cytotype of Viola riviniana from Finland. Annales Botanici Fennici 40: 395-400.

Hodálová, I., Mered'a, J.P., Mártonfi, P., Mártonfiová, L. \& Danihelka, J. 2008. Morphological characters useful for the delimitation of taxa within Viola subsect. Viola (Violaceae): a morphometric study from the West Carpathians. Folia Geobotanica 43: 83-117.

Karlsson, T., Marcussen, T., Wind, P. \& Jonsell, B. 2008. Violaceae. In: Karlsson, T. (ed.), Flora Nordica Vol. 6. Stockholm: The Bergius Foundation (http://www.floranordica.org/Review/-Review_public/accounts/Viola.html).

Knaben, G. \& Engelskjön, T. 1967. Chromosome numbers of Scandinavian arctic-alpine plant species. II. Acta Borealia, ser. A, 21: $1-57$.

Kuta, E. 1990. Biosystematic studies on the genus Viola L., section Plagiostigma Godr. 1. Karyological analysis of V. epipsila Ledeb., V. palustris L. and their hybrids from Poland. Acta Biologica Cracoviensia. Series Botanica 31: 29-44.

Laínz, M. 1962. Aportaciones al conocimiento de la flora cántabro-astur, VI. Boletín de Ciencias de la Naturaleza. Real Instituto de Estudios Asturianos 5: 3-43.

Laínz, M. 1967. Aportaciones al conocimiento de la flora gallega, V. Anales del Instituto Nacional de Investigaciones Agrarias. Serie Forestal 12: 1-51.

Laínz, M. 1992. Sobre la distribución ibérica de Viola reichenbachiana Jord. ex Boreau. Anales del Jardín Botánico de Madrid 50(2): 267-268

Larsen, K. 1954. Chromosome numbers of some European flowering plants. Botanisk Tidsskrift 50: 163-174.

Lee, H.C. \& Lin, T.Y. 2005. Isolation of plant nuclei suitable for flow cytometry from recalcitrant tissue using a filtration column. Plant Molecular Biology Reporter 23: 53-58.

Leitch, I.J. \& Bennett, M.D. 2007. Genome size and its uses: the impact of flow cytometry. In: Doležel, J., Greilhuber, J. \& Suda, J. (eds.), Flow cytometry with plant cells. Analysis of genes, chromosomes and genomes. Wiley-VCH Verlag, Weinheim, 153-176.

Loureiro, J. 2007. Flow cytometric approaches to study plant genomes. PhD Thesis, University of Aveiro, Aveiro.

Loureiro, J., Rodriguez, E., Doležel, J. \& Santos, C. 2007a. Two new nuclear isolation buffers for plant DNA flow cytometry - a test with 37 species. Annals of Botany 100: 875-888.

Loureiro, J., Rodriguez, E., Gomes, A. \& Santos, C. 2007 b. Genome size estimations on Ulmus minor Mill., Ulmus glabra Huds. and Celtis australis L. using flow cytometry. Plant Biology 9: 541-544.

Löve, A. \& Kjellqvist, E. 1974. Cytotaxonomy of Spanish plants. IV. Dicotyledons: Caesalpiniaceae-Asteraceae. Lagascalia 4(2): 153-211.

Lysák, M.A. \& Doležel, J. 1998. Estimation of nuclear DNA content in Sesleria (Poaceae). Caryologia 52: 123-132.

Marcussen, T. 2003. A new violet species (Violaceae) from the south-west Alps. Botanical Journal of the Linnean Society 142: 119-123.

Marcussen, T. \& Nordal, I. 1998. Viola suavis, a new species in the Nordic flora, with analyses of its relation to other species in the subsection Viola (Violaceae). Nordic Journal of Botany 18: 221237.

Mered'a, P., Hodálová, I., Mártonfi, P. \& Kolarcik, V. 2006. Reports (17-22). In: Mráz, P. (ed.), Chromosome number and DNA ploidy level reports from Central Europe - 2. Biologia, Bratislava 61(1): 116-117.

Mered'a, P., Hodálová, I., Mártonfi, P., Kučera, J. \& Lihová, J. 2008. Intraspecific variation in Viola suavis in Europe: parallel evolution of white-flowered morphotypes. Annals of Botany 102: 443-462.

Merxmüller, H. 1974. Veilchenstudien. I-IV. Phyton 16: 137-158.

Merxmüller, H. \& Lippert, W. 1977. Veilchenstudien V-VII. Mitteilungen (aus) der Botanischen Staatssammlung München 13: 503-531.

Miyaji, Y. 1930. Betrachtungen über die Chromosomenzahlen von Viola, Violaceen und verwandten Familien. Planta 11: 631-649.

Montserrat, P. 1992. Las violas y los problemas que plantean. Anales del Jardín Botánico de Madrid 49(2): 298-301.

Moore, D.M. 1982. Flora Europaea check-list and chromosome index. Cambridge University Press, Cambridge.

Morgan, H.D. \& Westoby, M. 2005. The relationship between nuclear DNA content and leaf strategy in seed plants. Annals of Botany 96: 1321-1330.

Muñoz Garmendia, F., Montserrat, P., Laínz, M. \& Aldasoro, J.J. 1993. Viola. In: Castroviejo, S., Aedo, C., Cirujano, S., Laínz, M., Montserrat, P., Morales, R., Muñoz Garmendia, F., Navarro, C., Paiva, J., Soriano, C. (eds.), Flora Iberica. Plantas vasculares de la Península Ibérica e Islas Baleares Vol. III. Real Jardín Botánico, CSIC, Madrid, 276-317.

Noirot, M., Barre, P., Duperray, C., Hamon, S. \& De Kochko A. 2005. Investigation on the causes of stoichiometric error in genome size estimation using heat experiments: consequences on data interpretation. Annals of Botany 95: 111-118.

Noirot, M., Barre, P., Duperray, C., Louarn, J. \& Hamon, S. 2003. Effects of caffeine and chlorogenic acid on propidium iodide accessibility to DNA: consequences on genome size evaluation in coffee tree. Annals of Botany 92: 259-264.

Noirot, M., Barre, P., Louarn, J., Duperray, C. \& Hamon, S. 2000. Nucleuscytosol interactions - a source of stoichiometric error in flow cytometric estimation of nuclear DNA content in plants. Annals of Botany 86: 309-316.

Noirot, M., Barre, P., Louarn, J., Duperray, C. \& Hamon, S. 2002. Consequences of stoichiometric error on nuclear DNA content evaluation in Coffea liberica var. dewevrei using DAPI and propidium iodide. Annals of Botany 89: 385-389.

Nordal, I. \& Jonsell, B. 1998. A phylogeographic analysis of Viola rupestris: three post-glacial immigration routes into the Nordic area? Botanical Journal of the Linnean Society 128: 105-122.

Otto, F. 1990. DAPI staining of fixed cells for high-resolution flow cytometry of nuclear DNA. In: Crissman, H.A. \& Darzynkiewicz, Z. (eds.), Methods in Cell Biology (Vol. 33). Academic Press, New York, 105-110.

Pettet, A. 1964. Studies on British pansies. I. Chromosome numbers and pollen assemblages. Watsonia 6: 39-50.

Pfosser, M., Amon, A., Lelley, T. \& Heberle-Bors, E. 1995. Evaluation of sensitivity of flow cytometry in detecting aneuploidy in wheat using disomic and ditelosomic wheat-rye addition lines. Cytometry 21: 387-393.

Price, H.J., Hodnett, G. \& Johnston, J.S. 2000. Sunflower (Helianthus annuus) leaves contain compounds that reduce nuclear propidium iodide fluorescence. Annals of Botany 86: 929-934.

Sanso, A. \& Seo, M. 2005. Chromosomes of some Argentine angiosperms and their taxonomic significance. Caryologia 58: 171-177.

Schmidt, A. 1961. Zytotaxonomische Untersuchungen an europäischen Viola-Arten der Sektion Nominium. Öesterreichische Botanische Zeitschrift 108: 20-88.

Schmidt, A. 1964. Chromosomenzahlen südeuropaïscher ViolaArten der Sektion Melanium. Flora 154: 158-162.

Schöfer, G. 1954. Untersuchungen über die Polymorphie einheimischer Veilchen. Planta 43: 537-565. 
Skalinska, M., Pogan, E. \& Pogan, A.L. 1966. Further studies in chromosome numbers of Polish angiosperms Acta Biologica Cracoviensia. Series Botanica 9: 31-58.

Stork, A.L. 1971. Viola reichenbachiana Jord. on Åland - chromosome counts. Svensk Botanisk Tidskrift Utgifven af Svenska Botaniska Foreningen 65(2): 226-228.

Suda, J. 2004. An employment of flow cytometry into plant biosystematics. PhD Thesis, Charles University in Prague.

Suda, J., Kron, P., Husband, B.C. \& Trávníček, P. 2007. Flow cytometry and ploidy: applications in plant systematics, ecology and evolutionary biology. In: Doležel, J., Greilhuber, J., Suda, J. (eds.), Flow cytometry with plant cells. Analysis of genes, chromosomes and genomes. Wiley-VCH Verlag, Weinheim, 103-130.

Suda, J., Kyncl, T. \& Jarolímová, V. 2005. Genome size variation in Macaronesian angiosperms: forty percent of the Canarian endemic flora completed. Plant Systematics and Evolution 252: $215-238$.

Suda, J. \& Trávníček, P. 2006. Estimation of relative nuclear DNA content in dehydrated plant tissues by flow cytometry. In: Robinson, J.P., Darzynkiewicz, Z., Dobrucki, J., Hyun, W., Nolan, J., Orfao, A. \& Rabinovitch, P. (eds.), Current Protocols in Cytometry. John Wiley \& Sons, New York, 7.30.1-7.30.14.

Talent, N. \& Dickinson, T.A. 2005. Polyploidy in Crataegus and
Mespilus (Rosaceae, Maloideae): evolutionary inferences from flow cytometry of nuclear DNA amounts. Canadian Journal of Botany 83: 1268-1304.

Tjio, J.H. \& Levan, A. 1950. The use of oxiquinoleine in chromosome analysis. Anales de la Estación Experimental de Aula Dei2: 21-64.

Valentine, D.H. 1941. Variation in Viola riviniana Rchb. New Phytologist 40: 189-209.

Valentine, D.H., Merxmüller, H. \& Schmidt, A. 1968. Viola L. In: Tutin, T.G., Heywood, V.H., Burges, N.A., Moore, D.M., Valentine, D.H., Walters, S.M. \& Webb, D.A. (eds.), Flora Europaea 2. Cambridge University Press, Cambridge, 270-282.

Van den Hof, K., van den Berg, R.G. \& Gravendeel, B. 2008. Chalcone synthase gene lineage diversification confirms allopolyploid evolutionary relationships of European rostrate violets. Molecular Biology and Evolution 25(10): 2099-2108.

Yockteng, R., Ballard, H.E., Mansion, Jr.G., Dajoz, I. \& Nadot, S. 2003. Relationships among pansies (Viola section Melanium) investigated using ITS and ISSR markers. Plant Systematics and Evolution 241: 153-170.

Associate Editor: A. Susanna Received: 20-X-2010 Accepted: 10-III-2011 